\title{
MST em governos petistas: as ruas refletem protestos amenos?
}

\section{Leonardo Joanes da Silva* (UNICAMP), prof.. Dr.․ Luciana Tatagiba (UNICAMP)}

\section{Resumo}

Uma proposta de interpretação descritiva acerca do modo como o Movimento dos Trabalhadores Rurais Sem-Terra (MST) atuou durante o governo da Presidente Dilma Rousseff (janeiro de 2011 até agosto de 2016, quando houve o impeachment da presidente eleita). Para a realização deste estudo foi utilizada uma base de dados intitulada de Conflito Político no Brasil (1998-2016) elaborado pelo Núcleo de Pesquisa de Participação e Ação Coletiva (NEPAC) junto ao CEMARX (Centro de Estudos Marxistas) da UNICAMP.

\section{Palavras-chave:}

Movimento dos Trabalhadores Rurais Sem-Terra, Ação coletiva,Governo de aliado

\section{Introdução}

O MST é um movimento social importante devido à sua envergadura quanto à capacidade de mobilização, trajetória no cenário político nacional por esse motivo se configura como referencial empírico para estudo da relação entre Estado e sociedade civil nos anos do Governo Rousseff (2011-2016).

Nas últimas décadas foram feitas análises que apontavam para a redução do uso da estratégia disruptiva que é característica do Movimento, a ocupação de terras (CORREA, 2013); e outras questões que cortejam a tese de apassivamento, cortejada tanto por estudiosos quanto referida por dissidentes do movimento.

Nesta pesquisa procuro através do banco de dados Conflito Político no Brasil (1998-2016) feito pela NEPAC e CEMARX, verificar se através das notícias trazidas pelo jornal Folha de São Paulo há informações de um possível processo de admoestação do conflito social ou se pode indicar outros processos internos.

\section{Resultados e Discussão}

- Segundo o banco, a frequência dos protestos do MST diminuiu consideravelmente durante 0 primeiro mandato de Dilma, caindo $57,1 \%$.

- Esse cenário de recrudescimento acabou sendo revertido devido ao cenário de crise política ocorrido no começo do segundo mandato, que culminou no processo de impeachment. Esse aumento da frequência vinha de uma demonstração de apoio crítico ao Governo Federal, em rejeição às movimentações de queda da presidente Dilma Rousseff.

Gráfico 1|-Repertório de ação recorrente do MST (2011-2016)

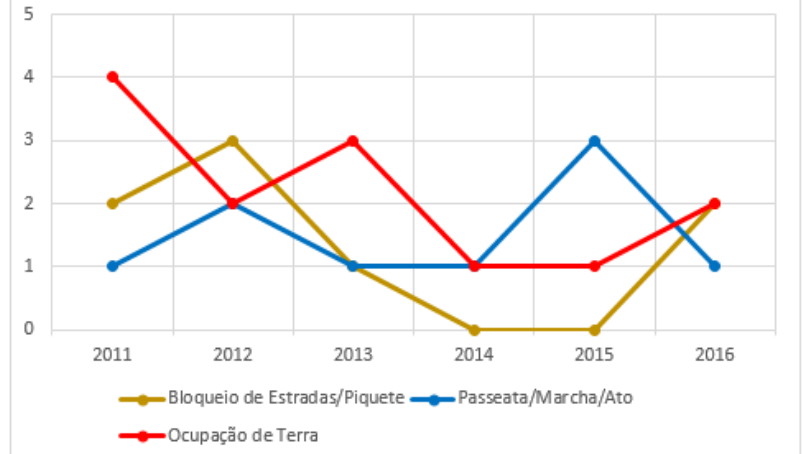

FONTE: Confronto político no Brasil (1998-2016) - NEPAC/CEMARX
- Segundo o Gráfico 1, a ocupação de terra, repertório por excelência do MST, apresenta uma tendência à queda.

Gráfico 2 - Relação entre a base social sem-terra e MST (2011-2017)

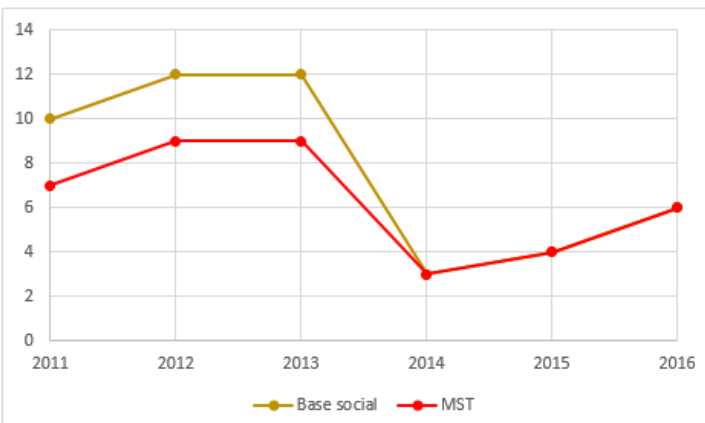

FONTE: Confronto político no Brasil (1998-2016) - NEPAC/CEMARX

- A participação do MST teve uma queda abrupta em 2013, recuperando-se moderadamente a partir de 2015. Porém, para os setores da grande mídia, o MST ainda se configura como o principal ator na elaboração da demanda pela terra.

\section{Conclusões}

Com a utilização do banco de dados pôde-se verificar a atuação do MST demonstra que a demanda pela terra não esmoreceu no discurso do Movimento, desde 2011 vê-se a centralidade deste tema dentre os objetivos que lideram suas manifestações ao lado das demandas políticas associadas a defesa de políticos, política econômica e atenção ao meio ambiente.

\section{Agradecimentos}

Agradeço imensamente à prof. a Luciana Tatagiba pelo incentivo e disposição para realizar as orientações e ao CNPq pela oportunidade de realização da pesquisa.

COLETTI, Claudinei. Avanços e impasses do MST e da luta pela terra no Brasi nos anos recentes. In: José Seoane. (Org.). Movimientos Sociales y Conflicto en América Latina. Buenos Aires: Clacso, 2003, v. , p. 73-84.

CORRÊA, A. E. C. Movimentos Sociais e Estado: o governo do PT e o apassivamento do MST. In: V Simpósio Internacional Lutas Sociais na América Latina, 2013, Londrina. Anais do V Simpósio Internacional Lutas Sociais na América Latina/2013. Londrina: GEPAL, 2013. v. 1. p. 42-57. 